\title{
Designing Game "Belajar Hanacaraka” As A Javanese Script Learning Media
}

\author{
Yonathan Happy Setiawan \\ 13070065@student.unika.ac.id \\ Information System Department, Faculty of Computer Science \\ Soegijapranata Catholic University, Indonesia
}

\begin{abstract}
This paper discusses the design of games used as a medium of learning. The learning material is about Javanese script, which is taught from elementary to high school. Although it has been taught since elementary school, but not many students have mastered this material.
\end{abstract}

The method of delivering the material used by the lecturers is usually by lecturing so that students become tired and bored, because they are forced to remember without understanding the basic concepts. The lack of an attractive and modern learning tool becomes another obstacle to the difficulty of studying the Javanese script.

Games usually used as entertainment, now can be used for learning. Through the game, the learning process becomes more fun. Therefore it will be designed an educational game used for learning Javanese script. But to design the right educational game, research is needed. With the presence of this game is expected players can learn Javanese script material while playing.

Keywords - Education Games, Games, Hanacaraka, Javanese Script

\section{INTRODUCTION}

Games usually used as a means of entertainment, but now the game is also used as a medium of learning. Through the game, learning can be more fun. To design the game in accordance with the intended material, it takes research so that the results of the game created can load learning materials more optimally.

In the lesson of Javanese language, Javanese script is the usual material learned from elementary to high school. Although it has been studied since elementary school, but for some students of Java script still difficult to master.

According to the article entitled "Media Pembelajaran Interaktiv Aksara Jawa Berbasis Flash" which has published in 2012, the delivery of materials used by teachers is lectures, so that the average student will feel tired and bored to learn, because what they do is remember without understanding the basic concept [1]. In addition, other constraints are the lack of an attractive, interactive, and modern learning tool [2].

In general, the delivery of Javanese script material in schools still uses conventional methods. Therefore, "Belajar Hanacaraka" (Learning Hanacaraka) is an educational game designed as a medium for learning Javanese script. The educational game is a game devoted to education. Through the educational game, the material is delivered through an interesting and interactive media. With "Belajar Hanacaraka", is expected to help players in learning and mastering Javanese script. The choice of games as learning media is because players can play while learning. 


\section{LITERATURE REVIEW}

\subsection{Games}

Video games are electronic games that use user-interface interactions through images generated by video devices. Video games usually provide a reward system, such as a score calculated based on the level of success achieved in completing tasks that exist within the game. Games requires players to solve problems in the most appropriate and fastest way [3].

\subsection{Casual Games}

Casual games are a type of game that is really intended only for entertainment purposes. This type of game is for everyone [4], both male and female, young and old. Simply, casual games are games that are far from complicated so there is no need for any special skills to play them, so it can be played by all ages [5]. The purpose of this game is to attract all circles.

\subsection{Educational Games}

Educational games are games devoted to education using interactive multimedia technology. This type of game supports for teaching and learning [6]. This game is used to convey learning and knowledge to players through a unique and engaging medium [7].

\subsection{Game Engine}

Game engine is a software used to create and develop games [8]. Game developers use game engine to create games from various platforms, either console, mobile, or PC. The existence of game engine provides tools to users to improve productivity in terms of game development [9]. With game engine, game making process become easier, faster, and efficient because it has various tools that can help users. Game engine is also used to create game "Belajar Hanacaraka", game engine used is Scirra Construct 2.

\section{RESEARCH METHODOLOGY}

The research method used in designing "Belajar Hanacaraka" is through literature study, observation, and survey method. The literature study was used to find problems about Javanese script learning. Observations are used to find and compare similar games that already exist. While the survey method is used to accommodate the opinions of people to design the game.

\section{RESULT AND DISCUSSION 4.1. Flowchart of Game Design}

There is the game making flowchart.

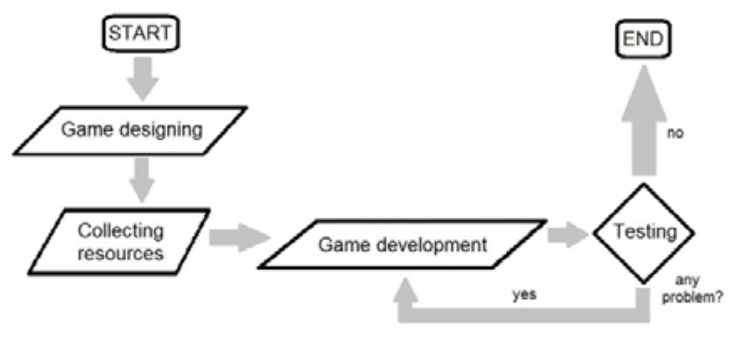

Fig. 4.1 Game making flowchart

The steps in game making of "Belajar Hanacaraka" are:

a. Designing the game, starting from the system till the game modes in it. Detailing what things can be done in the game.

b. Create and collect game assets. Create and collect the required assets in the game, such as: images, sounds, animations, and more.

c. Develop the game. At this stage will begin the process of game making. Assemble all resources, make it into a game.

d. Testing. This step will testing the game. Looking for bugs / errors in the game and fix it.

e. Fixed a bug in the game. After testing the game, fixing the errors that have been found. 


\subsection{Software Design}

In developing a game it takes some tools or softwares. Tools used to develop the game "Belajar Hanacaraka" are:

a. Construct 2. "Belajar Hanacaraka" developed by using Construct 2 r221 version. Construct 2 is an HTML 5 based game engine commonly used to create casual games with 2dimensional graphics. The output of Construct 2 also varied. "Belajar Hanacaraka" is created using Construct 2. The reason for choosing Construct 2 as a game tool is because Construct 2 is easy to use. With its drag-and-drop feature, it will make it easier during game development process.

b. Paint. The Paint application is used to edit game assets in the form of simple images. Paint is used because it is easy, simple, and lite software. Therefore this software is very effective and efficient for editing simple pictures.

c. Photoshop CS5 Portable. Photoshop is used to edit game assets in the form of complex images, which can not be created or edited with Paint software.

d. CorelDraw X7. CorelDraw is an image processing software just like Paint and Photoshop. CorelDraw is used to create game assets that may not be created with Paint and Photoshop.

e. Format Factory. Format Factory or commonly known as FF is a software that is able to change various file types (images, sound, video, etc.) from any extension to another extension. In making process of "Belajar Hanacaraka", Format Factory is used to convert sound files from .mp3 to .ogg, the purpose is because the sound files with the .ogg extension are more compatible with Construct 2.

\subsection{Game Assets}

Game assets in images form are made with image processing software, such as: Paint, Photoshop, and CorelDraw. Here are the image assets used in the "Belajar Hanacaraka".
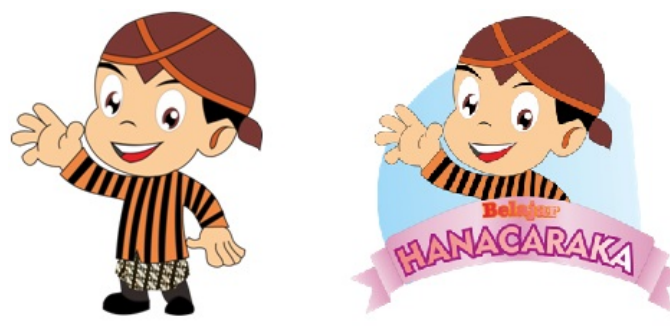

Fig. 4.2 Character of the game

The picture above is the characters and logos of "Belajar Hanacaraka". The characters wear traditional Javanese clothes complete with blangkon. The character is made to fit the theme of the game related to Javanese tradition.

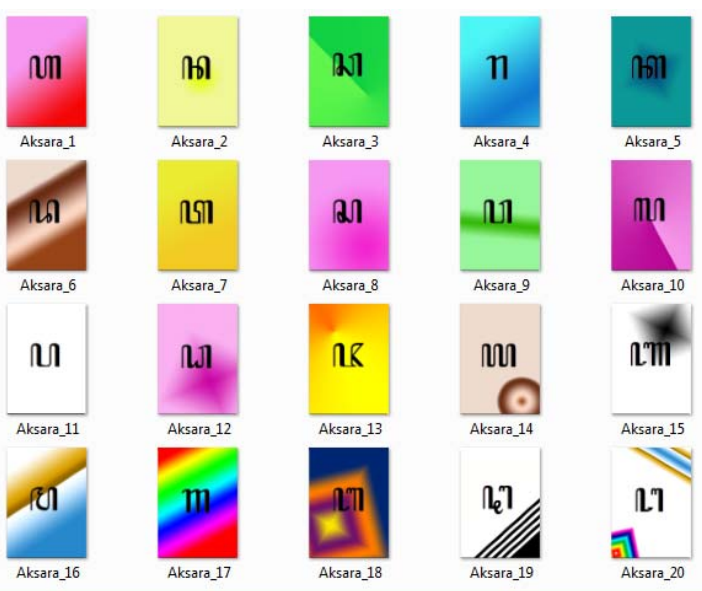

Fig. 4.3 Sprites used at "Memory Match" mode 


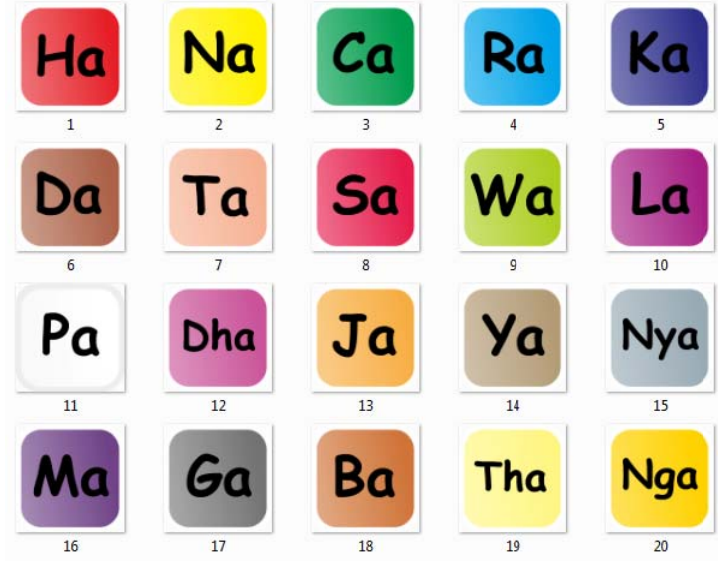

Fig. 4.4 Sprites used in the last mode

The picture above is the sprites of Javanese script used in "Memory Match" and "Tangkap Air" mode.

\subsection{Flowchart of the Game}

There is the flowchart of the game.

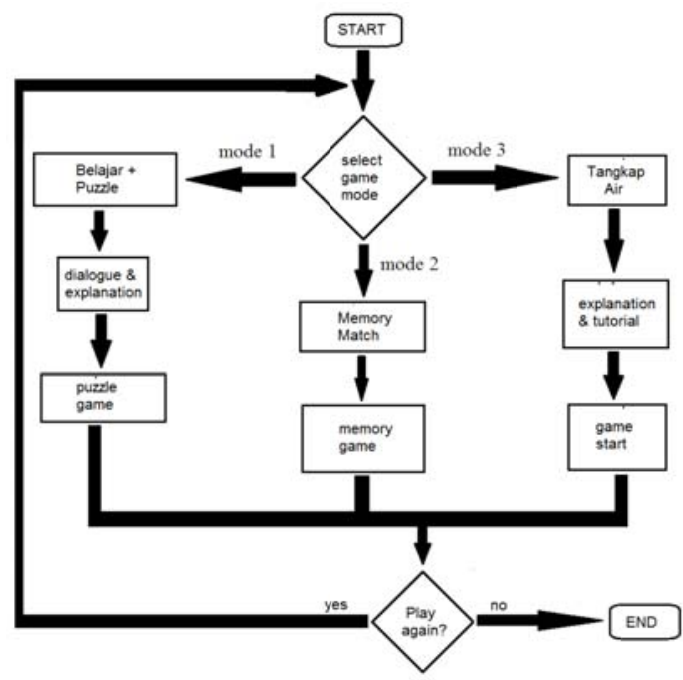

Fig. 4.5 Flowchart of the game

In "Belajar Hanacaraka", there are 3 main modes. After the game starts, players can freely choose which mode will be played first. After the game mode is complete, the player can re-play the mode or choose to play the other mode. Each mode has its own uniqueness. In "Belajar + Puzzle" (Learning + Puzzle) mode, players play by drag-anddrop puzzle pieces in the space provided. In
"Memory Match" mode, players are required to remember and find each cards with their pair. In "Tangkap Air" (Catch the Water) mode, players will more actively tap the screen and survive as long as possible to get the highest score.

\section{CONCLUSIONS}

Based on the literature study from several journals which revealed that the method of delivering Javanese script is still using conventional method, and the lack of interesting and modern media, it can be concluded that the Javanese-themed educational game is necessary to assist players in learning Javanese script while playing games.

\section{ACKNOWLEDGMENT}

Yonathan Happy Setiawan is recipient of scholarship from Ministry of Education and Culture of Indonesia (Beasiswa Unggulan Kemendikbud RI) in 2012 for Information System in Soegijapranata Catholic University, Semarang.

\section{REFERENCES}

[1] H. A. Wijayanti and F. N. Hakim, "Media Pembelajaran Interaktiv Aksara Jawa Berbasis Flash,” J. Teknol. Inf. dan Komun., vol. 3, p. 21, 2012.

[2] V. I. Ekowati, "Perubahan Sistem Pembelajaran Aksara Jawa," in Seminar Nasional Pembelajaran Bahasa dan Sastra Daerah dalam Kerangka Budaya Jawa, 2007, p. 2.

[3] A. T. S. Nugroho, "Definisi Game dan Jenis-Jenisnya,” 2011. [Online]. Available:

https://chikhungunya.wordpress.com/2011/0 
5/26/definisi-game-dan-jenis-jenisnya/.

[Accessed: 16-Sep-2015].

[4] A. Derryberry, "Serious Games: Online Games for Learning,” Adobe Serious Games Whitepaper, p. 3, 2007.

[5] M. W. Wibowo, "Perancangan dan Pembuatan Game 'Escape the Ball' untuk Smartphone Android,” J. Chem. Inf. Model, vol. 53, no. 9, pp. 1689-1699, 2013.

[6] Andriansyah, "Perancangan Aplikasi Game Edukasi Menggunakan Metode Linear Congruent Method (LCM)," Pelita Inform. Budi Darma, vol. VI, no. 1, p. 82, 2014.

[7] G. D. Putri, "Pengembangan Game Edukasi Pengenalan Nama Hewan Dalam Bahasa Inggris Sebagai Media Pembelajaran Siswa SD Berbasis Macromedia Flash,” p. 10, 2012.

[8] R. Spear, C. Rivet, S. Killingsworth, and A. Kumar, "Designing and Creating A Game Engine for Use in The Classroom," Comput. Game Dev. Educ. An Int. J., vol. 1, no. 1, p. 1, 2013.

[9] A. Winarno, "Pengertian Game Engine,” 2012. [Online]. Available: http://cakrawalamaya.blogspot.co.id/2012/03 /pengertian-game-engine.html. [Accessed: 16-Sep-2015]. 